\title{
Capturing the Performance of the Indonesian Sharia Stock Index (ISSI) and Composite Share Price Index (IHSG) Jakarta During Bullish and Bearish Period 2016-2019
}

\author{
Muhammad Hanif al Hakim ${ }^{1, \text { a }}$ \\ ${ }^{1}$ Department of Islamic Economic Laws, Faculty of Sharia and Law, \\ IAIN Surakarta \\ Jl. Pandawa, Pucangan, Kartasura, Sukoharjo, Jawa Tengah, Indonesia \\ a muhammadhanifalhakim@gmail.com
}

DOI: https://doi.org/10.22219/jes.v5i2.12729

Check for updates

\begin{tabular}{ll}
\hline & \multicolumn{1}{c}{ ABSTRACT } \\
\cline { 2 - 2 } $\begin{array}{l}\text { Keywords: } \\
\text { Stock Index; }\end{array}$ & This study aims to compare the performance of Indonesia Sharia Stock \\
Shabice; & Index (ISSI) and Composite Share Price Index (IHSG) Jakarta over bullish \\
Stability; & dan bearish period 2016-2019. This research is descriptive quantitative \\
Volatility, & $\begin{array}{l}\text { using natural log and standard deviation calculation. The data retrieved } \\
\text { Market Return }\end{array}$ \\
& $\begin{array}{l}\text { from Financial Service Autority. The finding show that indexes whose } \\
\text { volatility values are high does not always generate high positive returns. In } \\
\text { addition, the performance of the two indices showed the same pattern in } \\
\text { both bullish and bearish periods despite the differences in some conditions } \\
\text { and systems. }\end{array}$ \\
\hline
\end{tabular}

Article Info:

Submitted:

29/06/2020

Revised:

25/07/2020

Published:

30/08/2020

How to cite: al-Hakim, M. H. (2020). Capturing the Performance of Indonesian Sharia Stock Index (ISSI) and Composite Share Price Index (IHSG) Jakarta Period 2016-2019. Falah: Jurnal Ekonomi Syariah, 5(2), 84-98. doi. https://doi.org/10.22219/jes.v5i2.12729 
Vol. 5 No. 2 (2020)

ISSN (print): 2502-3918 | ISSN (online): 2502-7824

\section{INTRODUCTION}

The capital market has a very important role in the current global economy (Chen, \& Siems, 2004; Cheung, Fung, \& Tsai, 2010; Ahmad \& Radzi, 2011). As an investment instrument in Indonesia where the financial market is developing, the capital market has become an important part of the country's economy (Kim, \& Song, 2017; Santiago, 2017; Rethel, 2018a; Rethel, 2018b). Both as a place to raise funds, an alternative place of investment through the sale of shares and bond issuance, as well as an indicator of stability in macroeconomic conditions (Flaherty, et. al., 2017; Odo, et. aI., 2017; Gebauer, et. al., 2018; Chipeta, 2020).

In the last four years, the Indonesian capital market saw 39.2\% growth from 4525.92 in early 2016 to 6299.54 at the end of 2019. The growth was a significant figure, compared to the growth of other countries' capital markets in one region. This high growth will ultimately affect other indices whose stock components are in the composite index (Cheng, et. al., 2020; Petry, et. al., 2019; Charfeddine, et. al., 2019; Gygli, et. al., 2019; Yeon, et. aI., 2020; Acharya, et. al., 2020).

The emergence of sharia products was initiated to accommodate the needs of Muslims who want to invest with sharia principles (Laldin \& Furqani, 2016; Todorof, 2018; Yumna, 2019; Shahabuddin, et. al., 2020; Nasir, et. al., 2020). Sharia investment products in the capital market continued to develop with the presence of sharia bond instruments (sukuk), sharia mutual funds, and Sharia Securities List (DES) which are then transformed into the Indonesian Sharia Stock Index (ISSI). It is supraising that the number of sharia shares listed on the exchange continues to experience a significant increase, especially with the 2015-2019 PMS Roadshow programme, as shown in the following figure.

Table 1. The Growth of Capital Markets in the Area

\begin{tabular}{llccc}
\hline Countries & Indeces & $\mathbf{2 0 1 6}$ & $\mathbf{2 0 1 9}$ & Growth (\%) \\
\hline Indonesia & IHSG & 4525.92 & 6299.54 & $39.19 \%$ \\
\hline Malaysia & KLSI & 1615.67 & 1653.37 & $2.33 \%$ \\
\hline Singapura & STI & 2835.97 & 3222.44 & $13.63 \%$ \\
\hline Thailand & SET & 1263.41 & 1579.84 & $25.05 \%$ \\
\hline Filipina & PSE & 6833.42 & 7815.26 & $14.37 \%$ \\
\hline Jepang & NIKKEI225 & 18450.98 & 23656.62 & $28.21 \%$ \\
\hline Hong Kong & HSI & 21327.12 & 28319.39 & $32.79 \%$ \\
\hline
\end{tabular}

The significant development of Islamic stocks is an indicator that Muslim and nonMuslim investors are starting to glance at Islamic-based stocks (Al Amine, 2016; Sherif, 2016; Ahmed, 2019; Al Balooshi, 2020; Duasa, et. al., 2020). Islamic stocks also have good resilience when the economy is experiencing a crisis (Ahmad \& Albaity, 2008; Majid, 2018; Cheong, 2020; Pratama \& Rizal, 2019; Hassan, et. al., 2020; Erragragui, et. al., 2018; Bahemia, 2019; N. Chang, et. al., 2020), because the Islamic capital 
market has a better ability to adapt to external crisis disruptions. As a matter of fact, it was proven in the 2008 during Subprime Mortage Crisis.

Besides the significant increase, the Sharia capital market is considered to be more stable so that investors can feel more secure and comfortable to invest their money in the products offered (Abu-Alkheil, et. al., 2017; Piliyanti, 2019; Goel, et. al., 2019; Hati, et. al., 2020).

Several research was conducted related to this topics. Hakim \& Rashidian (2000), examined the risks and returns of the Shariah stock market index in the United States. It was found that the Shariah stock index is still influenced by market independent factors (interest rates). Dharani \& Natarajan (2011) found that there was no difference between the Nifty Sharia daily return Index and Nifty Index. Significant differences only occur in July and September. On the other hand, Chiadmi \& Ghaiti (2012) found that the daily return of the Sharia index was asymmetrical and leptokurtic, unlike the Gaussian distribution. They also found a heteroscedaticity effect on both indexes.

Charles \& Darne, 2006; Acharya, et. al., (2009), found that the stock price index was strongly influenced by many variables including global and domestic economic and financial conditions, politics, investment atmosphere, security and the performance of the company concerned. While Beik \& Wardhana (2011) found that that a stable index has a lower level of volatility that can be measured by the standard deviation (SD) value of each index. The finding show that JII has a smaller SD so that it is more stable when it gets shaken than that of the Dow Jones Index, KLCI and IHSG.

Kasi, U., \& Muhammad, J. (2016), found that the Shariah screening methodologies implied in the United States is far more stringent than those implied in the selected Asian countries. Kumar \& Sahu (2017), found the presence of a long run equilibrium relation between macroeconomic indicators and Dow Jones Islamic India market index. On the other hand, Lusyana \& Sherif (2017) found that the inclusion of the ISSI has a positive impact on the financial performance of the included shares during the 41-day event window. Furthemore, El Ouadghiri \& Peillex (2018), found that US public attention to Islamic terrorism negatively affects US Islamic indices, suggesting that investors may make amalgams between terrorism and Islamic finance.

While, Cheong, C. W. (2020) in his study on the effects of Shariah-compliance on non-financial firm operations on a global scale, found that resource restraints may be beneficial for a firm, and also provide significant value to firms looking to capitalize on the 1.8 billion-strong Muslim market with further insight on the intricacies of Shariahcompliance. Hassan, et. al., (2020) found that Islamic stock indices are less volatile than conventional stock indices. Anwer, et, al,. (2020) found that better governance, lower asset growth and lower equity or assets increase the propensity of SC firms to make higher repurchases. Robiyanto, (2018) found that gold can serve as a safe haven asset for sharia stocks in Indonesia at thet extreme shocks occur in the Indonesian stock market. Sherif, M. (2020) found a strong and statistically significant relationship between the COVID-19 pandemic and the performance of the conventional stock market index. 
However, those research is limited to a particular condition on Islamic stock indices and conventional stock indices in some country and religion, while this study compares the stability and performance of Indonesia Sharia Stock Index (ISSI) and Jakarta Composite Index (IHSG) over bullish dan bearish period between 2016-2019 in Indonesia. Bullish and bearish market conditions can be seen by classifying when the market return is higher or lower than the median (middle value) of the market return during the observed period (Fabozzi \& Francis, 2001). The bullish and bearish periods can be classified as daily, weekly and monthly. The total daily bullish and bearish period was 485 days, the weekly was 103 weeks and the monthly was 23 months. Weekly return data is based on five trading days in a week. Monthly return data is based on 20 active trading days in a month. The purpose of this is to determine the stability and performance of Indonesia Sharia Stock Index (ISSI) and Composite Share Price Index (IHSG) Jakarta over bullish dan bearish period between 2016-2019 in Indonesia.

\section{RESEARCH METHOD}

This research is descriptive quantitative and using natural log and standard deviation calculation. The data used is secondary data with data collection techniques retrieved from Financial Service Autority. The level of stability was indicated by the annualized volatility value, while the performance indicated by the return value. It is known that the level of volatility for both equally under $30 \%$, which indicates a safe market for investment.

This research used IHSG and ISSI as market proxies in calculating market returns. The calculation results was certainly differ from one another because the composition of the shares in it is also different. Composite Share Price Index (IHSG) Jakarta consists of all shares listed on the IDX while the ISSI component consists of all listed shares included on DES. The difference in the return value between the two indices and an analysis of the possibilities of what causes it, are expected to answer the problem of this research.

The initial stage in this research was to calculate the return of each ISSI and IHSG index. Return calculation can be done using logarithmic or arithmatic formulas. The results of the calculation of returns between the two methods have differences in value that was not too large. The difference between the results of the calculation of the average return of the two indices obtained by the calculation of the two methods was 0.00003394239 for ISSI and 0.00003237756 for the IHSG. 


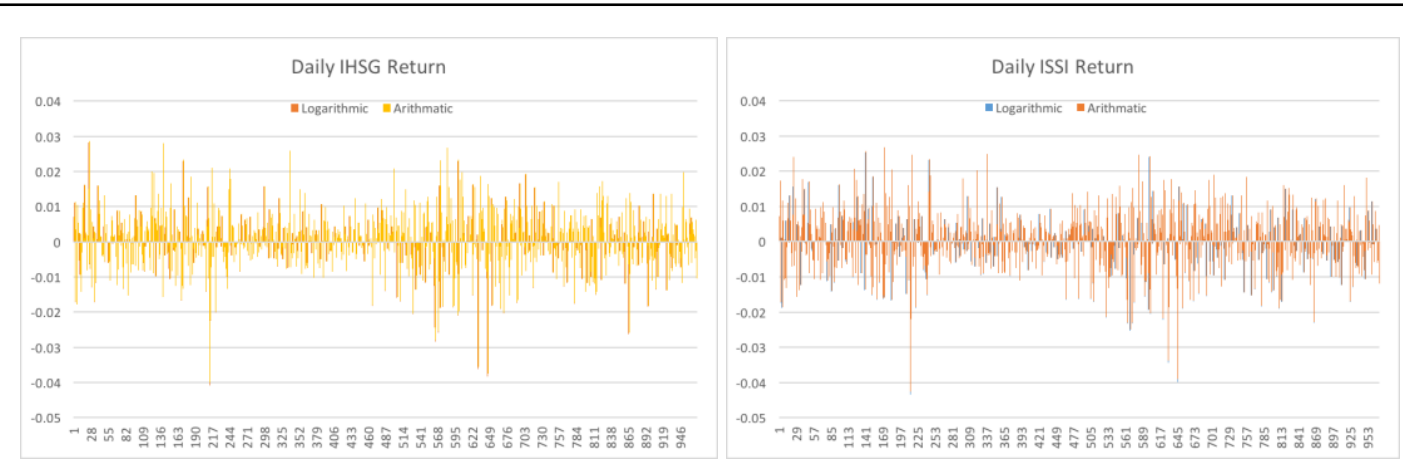

Figure 1. The Daily Return of ISSI and IHSG

The average ISSI return value with the logarithmic formula is 0.000271768 , while the average arithmatic formula is 0.000305711 . For IHSG, the average return value with the logarithmic formula is 0.000333619 , while the average arithmatic formula is 0.000365996 .

Table 2. The Return Calculation Results

\begin{tabular}{lll}
\hline Index & Average (Logaritmic) & Average (Aritmatik) \\
\hline ISSI & 0.000271768 & 0.000305711 \\
\hline IHSG & 0.000333619 & 0.000365996 \\
\hline
\end{tabular}

The calculation of returns by logarithmic had a smaller value compared to arithmatic. This study used returns from the results of arithmatic calculations as a tool to calculate the stability of ISSI and IHSG, because the opinion of Hudson (2010) which states that the arithmatic method was more suitable than logarithmic to calculate the index return.

The data analysis technique used in this study was qualitative data analysis following three phases namely: data reduction, data display, and drawing a conclusion (Miles \& Huberman, 1992)

\section{RESULT AND DISCUSSION}

The result indicates that during the observed period, the annualized volatility of the ISSI return was higher than the IHSG return. The Table 3, show that the number of bullish periods is equal to the number of bearish periods.

Table 3. The Bullish and Bearish Period

\begin{tabular}{llr}
\hline \multicolumn{1}{c}{ Category } & ISSI & IHSG \\
\hline \multicolumn{1}{c}{ Median } & Daily & \\
\hline Sum of Return (Bull) & 0.000481799 & 0.000747626 \\
\hline Sum of Return (Bear) & 3.168674557 & 3.071202072 \\
\hline Jumlah Periode Bullish & -2.872311429 & -2.716567196 \\
\hline Jumlah PeriodeBearish & 485 & 485 \\
\hline & 485 & 485 \\
\hline
\end{tabular}


Vol. 5 No. 2 (2020)

ISSN (print): 2502-3918 | ISSN (online): 2502-7824

\begin{tabular}{llr}
\hline Median & 0.001712279 & 0.001710289 \\
\hline Sum of Return (Bull) & 1.398002019 & 1.419500169 \\
\hline Sum of Return (Bear) & -1.103852962 & -1.063613531 \\
\hline Jumlah Periode Bullish & 103 & 103 \\
\hline Jumlah PeriodeBearish & 103 & 103 \\
\hline \multicolumn{1}{c}{ Median } & Monthly & 0.005013659 \\
\hline & 0.005214773 & 0.636866734 \\
\hline Sum of Return (Bull) & 0.629158689 & -0.403096518 \\
\hline Sum of Return (Bear) & -0.477205867 & 23 \\
\hline Jumlah Periode Bullish & 23 & 23 \\
\hline Jumlah PeriodeBearish & 23 & \\
\hline
\end{tabular}

Returns on the weekly and monthly categories have the same pattern, namely the ISSI positive return is not greater than the IHSG positive return and the ISSI negative return (risk) is greater than the IHSG negative return (risk). In contrast to the daily category where the ISSI positive return is greater than the positive IHSG return when the market is in bullish and the negative return (risk) ISSI exceeds the negative return (risk) IHSG when the market is in bearish.

After the bullish and bearish periods for ISSI and IHSG was identified, a length of selected period will be single out whereby the return of one index has a consistent trend. Then the return of that index will be compared to the other index returns. Based on the results of data processing, three patterns of market movement whose events and issues that are suspected to contribute to the fluctuation of the return of the two indices will be discussed. It could be from the political situation, domestic and foreign economies, government and company policies, and others. Three groups of market movement to be analyzed are as shown in the following table 4 below:

Table 4. Three Groups of Market Movement Patterns

\begin{tabular}{cl}
\hline Series & \multicolumn{1}{c}{ Period } \\
\hline $242-359$ & December 27, 2016 - June 22, 2017 \\
\hline $423-500$ & October 3, 2017 - January 24, 2018 \\
\hline $763-819$ & February 27, 2019- May 23, 2019 \\
\hline
\end{tabular}

The comparison of ISSI and IHSG returns in the first group from December 27, 2016 to June 22, 2017. 118 active trading days in that time period are divided into six months. IHSG returns experienced bullish trend throughout the observed month while ISSI returns experienced five bullish months and one bearish month.

In general, economic conditions in 2017 recorded fairly good growth compared to the previous year, given the global economic recovery which has strengthened especially in the first and second quarter in a row. The economic recovery trend was also accompanied by an increase in world trade, an increase in commodity prices, business activity and global inflation (Bank Indonesia Report, 2018). All this is reflected in the growth of the Indonesian capital market from the level of 5275 at the beginning of the year to the level of 6355 at the end of the year, or growing by around $17 \%$. 
It can be seen in Figure 2 that the ISSI and IHSG curve lines are both experiencing an upward trend. The number of ISSI returns during the six months of observation was 0.006816937 , while the IHSG return was 0.00804766 . Both indexes recorded positive returns in the first to fourth month. In the fifth month, ISSI's return and IHSG's return both declined. However, the ISSI graph shows a negative number, while the IHSG still shows a positive number. This can happen because screening process causes shares in ISSI to be no more diversified than shares in the IHSG, thereby limiting the potential for positive returns and negative returns at these times. Then in the sixth month ISSI and IHSG both recorded positive returns, even though the ISSI return was relatively smaller than the IHSG return. Thus it can be seen overall that the IHSG return is higher than the ISSI return.

Data analysis in the field shows that among the factors that might cause ISSI to record negative returns in the fifth month are inflation, a decrease in the four ISSI constituent indices and Net Purchase by Foreigners. Inflation can cause investors to sell shares and cause the index to fall. The Central Statistics Agency (BPS) released inflation data for May 2017 at 0.39 percent, far higher than the inflation in April 2017 which was only 0.09 percent (Bank Indonesia Report \& BPS, 2017).

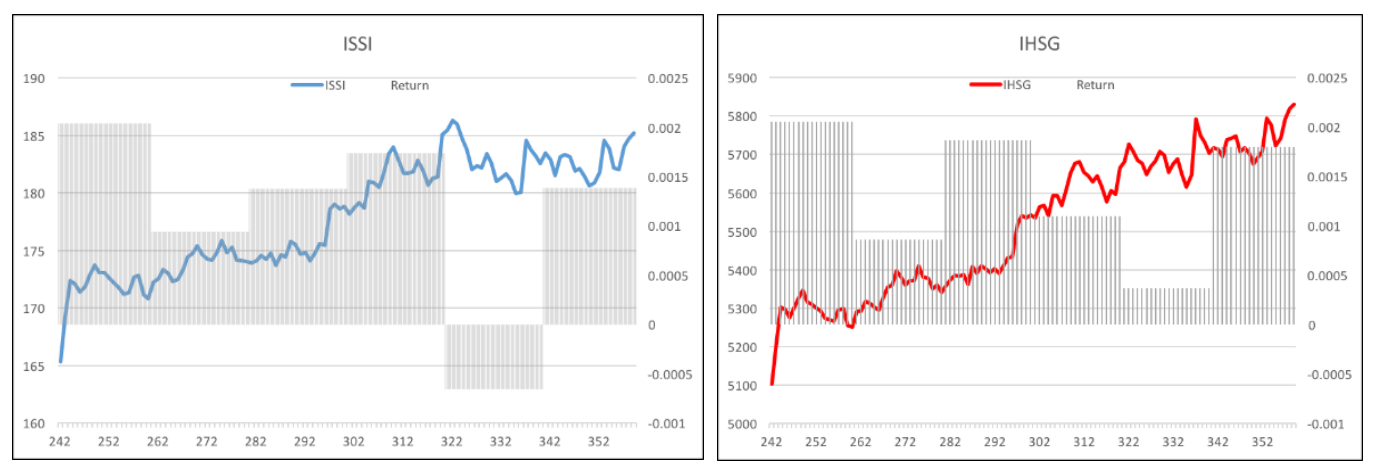

Figure 2. The Return of ISSI and IHSG over six months observed

In addition, four ISSI constituent indices such as mining, various industries, property, and infrastructure that showed negative growth could also impact ISSI's performance for the month. The four indexes fell by 131.8 points, 28.2 points, 13.5 points and 7.59 points respectively (Indonesia Stock Exchange (IDX), 2017). In May, the Net Purchase by Foreigners factor was also suspected to cause ISSI to drop to its lowest point in that month. It can be seen in Figure 3 that Net Purchase by Foreigners recorded a significant negative number for the month, which was close to minus 7000 Billion. 

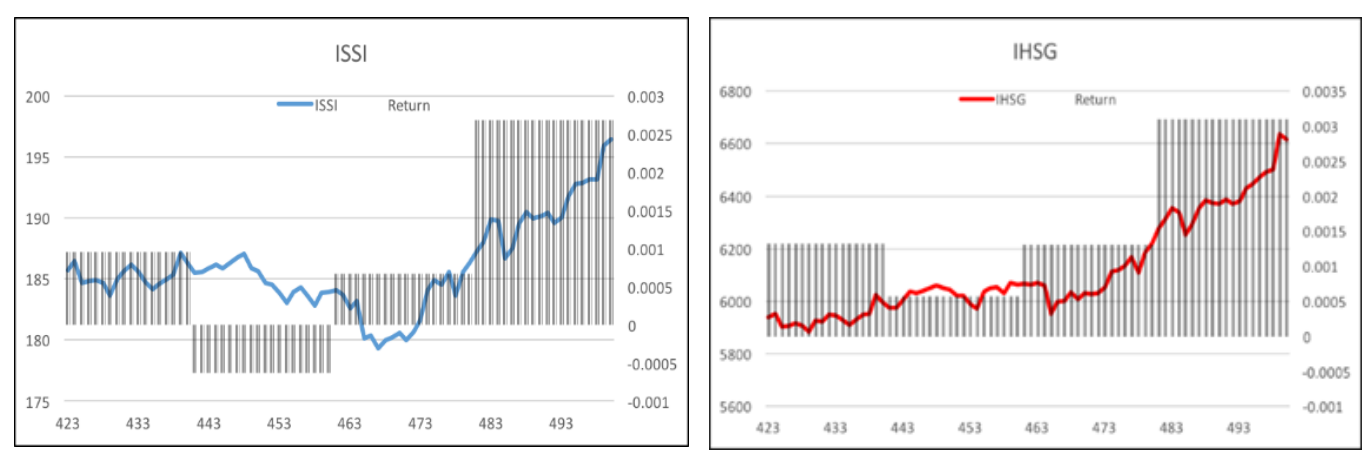

Figure 3. The Return of ISSI and IHSG over four months observed

The second analysis in this sub-chapter is the comparison of ISSI and IHSG returns in the second group of month from October 3, 2017 to January 24, 2018. 78 active trading days in that time period are divided into four months. IHSG returns experienced bullish trend throughout the observed months while ISSI returns experienced three bullish months and one bearish month.

The total ISSI return for four months of observation was 0.0036694 , while the IHSG return was 0.00629435. In the second month, between October 27, 2017 November 23, 2017, ISSI and IHSG returns declined. It's just that the ISSI return had recorded a negative number of $-0,0006314$, while the IHSG return was able to record a positive number of 0.00056668 . This pattern occurs exactly like what happened in the fifth month in Figure 4.

Data analysis in the field shows that among the factors that might cause the performance of ISSI and JCI to fall in the second month are market anticipation of the Fed's policy of raising interest rates in December 2017 and market responses to rebalancing the composition of the MSCI Indonesia Index. The indicators are the decline of 8 ISSI and IHSG constituent index compared to October 2018, and Net Purchase by Foreigners which recorded a negative number.
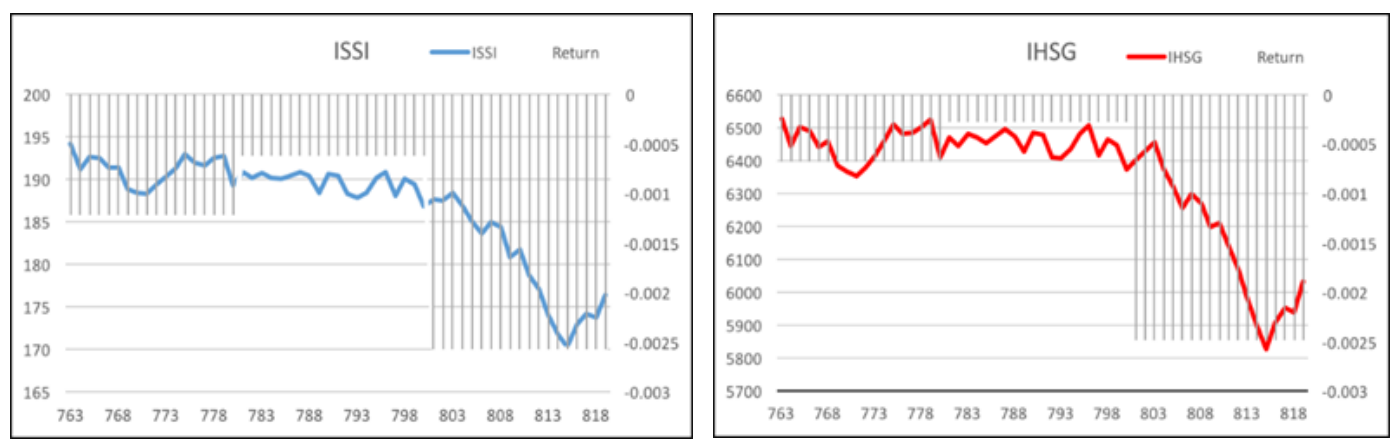

Figure 4. the Return of ISSI and IHSG over five months observed

The third analysis in this sub-chapter is the comparison of ISSI and IHSG returns in the third group of month from February 27, 2019 to May 23, 2019. 57 active trading days in that time period are divided into three months. ISSI and IHSG returns 
experienced bearish situation throughout the months with a total return of -0.0044106 for ISSI and -0.0034421 for IHSG. Thus it can be seen that the ISSI negative return is greater than the JCI negative return.

By and large, capital market growth throughout 2019 can be considered to be stagnant due to slow growth of global economic that year. As a result, the Indonesian capital market only recorded a slight increase, from the level of 6181 at the beginning of the year to a level of 6299 at the end of the year. The triggers for the weakening of global economic growth include a trade war between the United States and China that has not subsided. This has had an impact on a very slow economic recovery, such as a halt in sales of four-wheeled vehicles and cement for construction.

Based on the results, it has shown that during the observed period the annualized volatility of the ISSI return was higher than the IHSG return. According to Cohen (2009); Beik \& Wardhana (2011), this shows that ISSI is not more stable and has a greater risk profile and potential return compared to IHSG. According to Cohen (2009), the value of annualized volatility can be known from the multiplication of the standard deviation of the index with the root of the number of trading days in one year, or during the observation period.

This result was contrast from Beik (2011) which found that the Sharia stock index was more stable compared to other indices, which caused by differences in the types of data used in the two studies. Romli, et. al., (2011); Hassan \& Antoniou (2004), also prove that the Sharia index was more volatile than the conventional index. The high volatility in the Shariah stock index occurs because screening eliminates many companies from the entire population. As a result, companies that qualify will tend to be smaller in number and have volatile returns (Hassan, et. al., 2005). The return of each volatile issuer cumulatively will contribute to the volatility of the Shariah stock index so that the Shariah stock index is no more stable than the IHSG. Although the opportunity for diversification of the Sharia index is more limited compared to conventional indices, it does not mean the Shariah index is not attractive in terms of return. However, based on the annualized volatility value, both indexes are included in the index category which is quite stable because both have annualized volatility values below 30\% (Sarwar 2011).

\section{CONCLUSION}

Results from this study indicates that ISSI performance was no better than the IHSG's performance. This is base on the results of the return from the two indices in the three months observed in the time of bearish and bullish conditions. In a bearish condition, ISSI recorded a smaller positive return than of the IHSG. Even in certain cases, ISSI recorded a negative return in bearish conditions. In a positive bullish return condition, IHSG recorded positive greater return than of the ISSI.

However, future research may add wider population and sample of the study to find the more ideal model of the research and more valid result. 
Vol. 5 No. 2 (2020)

ISSN (print): 2502-3918 | ISSN (online): 2502-7824

\section{REFERENCES}

Abu-Alkheil, A., Khan, W. A., Parikh, B., \& Mohanty, S. K. (2017). Dynamic cointegration and portfolio diversification of Islamic and conventional indices: Global evidence. The Quarterly Review of Economics and Finance, 66, 212-224. https://doi.org/10.1016/j.qref.2017.02.005

Acharya, V. V., \& Richardson, M. P. (Eds.). (2009). Restoring financial stability: how to repair a failed system (Vol. 542). John Wiley \& Sons.

Acharya, V. V., Bhadury, S., \& Surti, J. (2020). Financial Vulnerability and Risks to Growth in Emerging Markets (No. w27411). National Bureau of Economic Research. Retrieved from https://www.nber.org/papers/w27411.pdf

Ahmad, R., \& Albaity, M. S. (2006). The Performance of Syariah and Composite Indices: Evidence from Kuala Lumpur Stock Market. Available at SSRN 1008840. http://dx.doi.org/10.2139/ssrn.1008840

Ahmed, M. R. (2019). Growth and challenges of the Islamic banking system: A perspective of the British Bangladeshi Muslim Community in London, United Kingdom (Doctoral dissertation, University of Wales Trinity Saint David). Retrieved from https://repository.uwtsd.ac.uk/1198/

Al Amine, M. A. B. M. (2016). Islamic finance and Africa's economic resurgence: Promoting diverse and localized investment. Springer.

Al Balooshi, S. (2020). Essays in Islamic finance and banking (Doctoral dissertation, University of St Andrews). Retrieved from https://research-repository.standrews.ac.uk/handle/10023/20174

Albaity, M., \& Ahmad, R. (2008). Performance of Syariah and composite indices: Evidence from Bursa Malaysia. Asian Academy of Management Journal of Accounting and Finance, 4(1), 23-43. Retrieved from

Anwer, Zaheer, Shamsher Mohamad, Andrea Paltrinieri, and M. Kabir Hassan. "Dividend payout policy of Shariah compliant firms: Evidence from United States." Pacific-Basin Finance Journal (2020): 101422. https://doi.org/10.1016/j.pacfin.2020.101422

Bahemia, N. (2019). The Resilience of Islamic Banks in the Wake of Crises: Comparing Islamic and Conventional Banks in the MENA Region. Retrieved from https://www.semanticscholar.org/paper/The-Resilience-of-Islamic-Banks-in-theWake-of-and-Bahemia/f04141dfa0b289059297b8fb33fa975da0fd743b?p2df

Beik, I. S., \& Wardhana, W. (2011). The relationship between Jakarta Islamic Index and other selected markets: evidence from impulse response function. Jurnal Ekonomi dan Bisnis Airlangga (JEBA), 21(2). Retrieved from https://www.neliti.com/publications/4100/the-relationship-between-jakartaislamic-index-and-other-selected-markets-eviden

Chang, B. H., Sharif, A., Aman, A., Suki, N. M., Salman, A., \& Khan, S. A. R. (2020). The asymmetric effects of oil price on sectoral Islamic stocks: New evidence from quantile-on-quantile regression approach. Resources Policy, 65, 101571, 1-12. https://doi.org/10.1016/j.resourpol.2019.101571

Charfeddine, L., \& Kahia, M. (2019). Impact of renewable energy consumption and financial development on $\mathrm{CO} 2$ emissions and economic growth in the MENA 
region: A panel vector autoregressive (PVAR) analysis. Renewable energy, 139(1), 198-213. https://doi.org/10.1016/j.renene.2019.01.010

Charles, A., \& Darné, O. (2006). Large shocks and the September 11th terrorist attacks on international stock markets. Economic Modelling, 23(4), 683-698. https://doi.org/10.1016/j.econmod.2006.03.008

Cheng, C. Y., Chien, M. S., \& Lee, C. C. (2020). ICT diffusion, financial development, and economic growth: An international cross-country analysis. Economic Modelling. https://doi.org/10.1016/j.econmod.2020.02.008

Cheong, C. W. (2020). Risk, Resilience, and Shariah-Compliance. Research in International Business and Finance, 55(1013130), 1-16. https://doi.org/10.1016/j.ribaf.2020.101313

Cheong, C. W. (2020). Risk, Resilience, and Shariah-Compliance. Research in International Business and Finance, 55(1013130), 1-16. https://doi.org/10.1016/j.ribaf.2020.101313

Chipeta, C. (2020). Analysis of South Africa's financial market relationship with business cycle indicators for financial stability (Doctoral dissertation, North-West University (South Africa)). http://repository.nwu.ac.za/handle/10394/34704

Cohen, G. 2009, Volatile Markets Made Easy, Pearson Education, Inc., USA.

Duasa, J., Sarif, S. M., \& Sabian, N. A. A. (2020). Unified theory of firm: an empirical analysis. Journal of Islamic Accounting and Business Research, 11(7), 14531478. https://doi.org/10.1108/JIABR-09-2018-0143

El Ouadghiri, I., \& Peillex, J. (2018). Public attention to "Islamic terrorism" and stock market returns. Journal of Comparative Economics, 46(4), 936-946. https://doi.org/10.1016/j.jce.2018.07.014

Erragragui, E., Hassan, M. K., Peillex, J., \& Khan, A. N. F. (2018). Does ethics improve stock market resilience in times of instability?. Economic Systems, 42(3), 450469. https://doi.org/10.1016/j.ecosys.2017.09.003

Flaherty, M., Gevorkyan, A., Radpour, S., \& Semmler, W. (2017). Financing climate policies through climate bonds-A three stage model and empirics. Research in International Business and Finance, 42, 468-479. https://doi.org/10.1016/j.ribaf.2016.06.001

Gebauer, S., Setzer, R., \& Westphal, A. (2018). Corporate debt and investment: A firmlevel analysis for stressed euro area countries. Journal of International Money and Finance, 86(1), 112-130. https://doi.org/10.1016/j.jimonfin.2018.04.009

Goel, S., kumar Srivastava, R., \& Dwivedi, S. (2019). Effects of Islamic Religious Practices on Investment Behaviour of Indian Muslims: A Qualitative Research in Delhi/NCR using Focus Group Method. Global Journal of Enterprise Information System, 11(1), 31-46. Retrieved from https://gjeis.com/index.php/GJEIS/article/view/38

Gygli, S., Haelg, F., Potrafke, N., \& Sturm, J. E. (2019). The KOF globalisation indexrevisited. The Review of International Organizations, 14(3), 543-574. https://doi.org/10.1007/s11558-019-09357-x 
Vol. 5 No. 2 (2020)

ISSN (print): 2502-3918 | ISSN (online): 2502-7824

Hakim, S., \& Rashidian, M. (2002, October). Risk and return of Islamic stock market indexes. In 9th Economic Research Forum Annual Conference in Sharjah, UAE (pp. 26-28). Retrieved from http://www.iefpedia.com/english/wpcontent/uploads/2009/09/Risk-Return-of-Islamic-Stock-Market-Indexes.pdf

Hassan, A. (2005). Impact of ethical screening on investment performance: the case of the Dow Jones Islamic Index. Islamic Economic Studies, 12(2), 1-31. Retrieved from http://iesjournal.org/english/Docs/094.pdf

Hassan, A., \& Antoniou, A. (2006). Equity fund's Islamic screening: Effects on its financial performance. Islamic Banking and Finance: Fundamentals and Contemporary Issues, Jeddah, Saudi Arabia: IRTI, 197-214. Retrieved from http://www.iefpedia.com/english/wp-content/uploads/2010/01/PFT149.pdf

Hassan, M. K., Aliyu, S., Saiti, B., \& Halim, Z. A. (2020). A review of Islamic stock market, growth and real-estate finance literature. International Journal of Emerging Markets. https://doi.org/10.1108/IJOEM-11-2019-1001

Hassan, M. K., Aliyu, S., Saiti, B., \& Halim, Z. A. (2020). A review of Islamic stock market, growth and real-estate finance literature. International Journal of Emerging Markets. https://doi.org/10.1108/IJOEM-11-2019-1001

Hati, S. R. H., Gayatri, G., \& Indraswari, K. D. (2020). Migration (Hijra) to Islamic bank based on push-pull-mooring theory: a services marketing mix perspective.

Journal of Islamic Marketing. https://doi.org/10.1108/JIMA-07-2019-0157

https://d1wqtxts1xzle7.cloudfront.net/45465656/Performance_of_Syariah_and_Compos ite Ind20160508-32503-pwulrr.pdf?1462765863=\&response-contentdisposition=inline\%3B+filename\%3DPerformance_of_Syariah_and_Composite_I nd.pdf\&Expires

Miles, M, B., \& Huberman, A, M. (1992). Qualitative Data Analysis. California: Sage Publication Inc.

Hudson, R. S. 2010. Comparing Security Returns is Harder Than You Think: Problems with Logarithmic Returns. UK: Newcastle University.

Hussein, K. A. (2007). Islamic investment: evidence from Dow Jones and FTSE indices. Advances in Islamic Economics and Finance: (Vol.1) Proceedings of The $6^{\text {th }}$ International Conference on Islamic Economics and Finance, pp. 387-347. Retrieved from https://d1wqtxts1xzle7.cloudfront.net/30903598/Advances-inIslamic-Economics-and-Finance-Volume-1by-Munawar-Iqbal-Salman-Syed-AliDadang-Muljawan.pdf?1362967625=\&response-content-

Kasi, U., \& Muhammad, J. (2016). Strict and uniform Shariah screening methodologies in selected Asian countries in comparison with the United States. Asian Journal of Finance \& Accounting, 8(1), 38-76. http://dx.doi.org/10.5296/ajfa.v8i1.8410

Kim, H., \& Song, J. (2017). Filling institutional voids in emerging economies: The impact of capital market development and business groups on M\&A deal abandonment. Journal of International Business Studies, 48(3), 308-323. Retrieved from https://link.springer.com/article/10.1057/s41267-016-0025-0

Kumar, K. K., \& Sahu, B. (2017). Dynamic linkages between macroeconomic factors and Islamic stock indices in a non-Islamic country India. The Journal of Developing Areas, 51(1), 193-205. https://doi.org.10.1353/jda.2017.0011 
Laldin, M. A., \& Furqani, H. (2016). Innovation versus Replication: Some Notes on the Approaches in Defining Shariah Compliance in Islamic Finance. Al-Jami'ah: Journal of Islamic Studies, 54(2), 249-272. https://doi.org/10.14421/ajis.2016.542.249-272

Lusyana, D., \& Sherif, M. (2017). Shariah-compliant investments and stock returns: evidence from the Indonesian stock market. Journal of Islamic Accounting and Business Research, 8(2), 143-160. https://doi.org/10.1108/JIABR-10-2015-0052

Majid, M. S. A. (2018). Stability and resilience of equity markets amidst the 2008 global financial crisis: Islamic versus conventional markets. DLSU Business \& Economics Review, 28(1), 34-48. Retrieved from http://dlsu-ber.com/wpcontent/uploads/2018/10/2majid-100218.pdf

McCauley, R. N., \& McGuire, P. (2009). Dollar appreciation in 2008: safe haven, carry trades, dollar shortage and overhedging. BIS Quarterly Review December. Retrieved from https://papers.ssrn.com/sol3/papers.cfm?abstract_id=1519814

Munusamy, D., \& Natarajan, P. (2011). Seasonal anomalies between S\&P CNX nifty Shariah index and S\&P CNX nifty index in India. Journal of Social and Development Sciences (JSDS), 1(3), 101-108. Retrieved from https://papers.ssrn.com/sol3/papers.cfm?abstract_id=2146398

Nasir, W. A. S. B. A., Hassan, R., \& Tijani, I. M. (2020). Malaysian's Government Linked Investment Companies: Is There a Need for Shariah Governance Framework?(Syarikat Pelaburan Berkaitan Kerajaan Malaysia: Adalah Adakah Perlu Rangka Kerja Tadbir Urus Syariah?). Journal of Islam in Asia, 17(2), 198222. https://doi.org/10.31436/jia.v17i2.961

Odo, S. I., Anoke, C. I., Onyeisi, O. S., \& Chukwu, B. C. (2017). Capital Market Indicators and Economic Growth in Nigeria; An Autoregrssive Distributed Lag (ARDL) Model. Asian Journal of Economics, Business and Accounting, 3(2), 116. Retrieved from http://eprints.gouni.edu.ng/1573/

Petry, J., Fichtner, J., \& Heemskerk, E. (2019). Steering capital: the growing private authority of index providers in the age of passive asset management. Review of International Political Economy, 1(1), 1-25. https://doi.org/10.1080/09692290.2019.1699147

Piliyanti, I. (2019). Fintech Achieving Sustainable Development: The Side Perspective of Crowdfunding Platform. Shirkah: Journal of Economics and Business, 3(2), 223-242. https://doi.org/10.22515/shirkah.v3i2.207

Pratama, S. D., \& Rizal, R. (2019). The Resilience of Islamic Banks in Facing the Economic Dynamics in Indonesia. Available at SSRN 3311990. http://dx.doi.org/10.2139/ssrn.3311990

Rethel, L. (2018a). Economic governance beyond state and market: Islamic capital markets in Southeast Asia. Journal of contemporary Asia, 48(2), 301-321. https://doi.org/10.1080/00472336.2017.1404119

Rethel, L. (2018b). Capital market development in Southeast Asia: From speculative crisis to spectacles of financialization. Economic anthropology, 5(2), 185-197. https://doi.org/10.1002/sea2.12116 
Vol. 5 No. 2 (2020)

ISSN (print): 2502-3918 | ISSN (online): 2502-7824

Robiyanto, R. (2018). Testing of the Gold's Role as a Safe Haven and Hedge for Sharia Stocks in Indonesia. Al-Iqtishad Journal of Islamic Economics, 10(2), 255-266. https://doi.org/10.15408/aiq.v10i2.6527

Romli, N., Mohamad, A. A. S., \& Yusof, M. F. M. (2012). Volatility analysis of FTSE Bursa Malaysia: Study of the problems of Islamic stock market speculation in the period 2007 to 2010. African Journal of Business Management, 6(29), 8490-8495. https://doi.org/10.5897/AJBM11.1049

Romli, N., Mohamad, A. A. S., \& Yusof, M. F. M. (2012). Volatility analysis of FTSE Bursa Malaysia: Study of the problems of Islamic stock market speculation in the period 2007 to 2010. African Journal of Business Management, 6(29), 8490-8495. https://doi.org/10.5897/AJBM11.1049

Santiago, F. (2017). Implementation of the role of notary through capital market in the ERA of ASEAN economic community. International Journal of Civil Engineering and Technology (IJCIET), 8(8), 1054-1059. Retrieved from https://www.researchgate.net/profile/Faisal_Santiago2/publication/319663298_Im plementation_of_the_role_of_notary_through_capital_market_in_the_ERA_of_as ean_economic_community/links/5c23230692851c22a3463e8c/Implementationof-the-role-of-notary-through-capital-market-in-the-ERA-of-asean-economiccommunity.pdf

Shahabuddin, A. S. M., Abd Sukor, M. E., \& Hashim, N. H. (2020). Product-centric halal business: a critique from an Islamic perspective. Journal of Islamic Marketing. https://doi.org/10.1108/JIMA-06-2019-0129

Sherif, M. (2016). Ethical Dow Jones indexes and investment performance: international evidence. Investment management and financial innovations, 13(2), 206-225. Retrieved from www.irbis-nbuv.gov.ua/cgibin/irbis_nbuv/cgiirbis_64.exe?C21COM=2\&I21DBN=UJRN\&P21DBN=UJRN \&IMAGE_FILE_DOWNLOAD=1\&Image_file_name=PDF/imfi_2016_13_2(con tin1) 10.pdf

Sherif, M. (2020). The impact of Coronavirus (COVID-19) outbreak on faith-based investments: An original analysis. Journal of Behavioral and Experimental Finance, 100403, 1-33. https://doi.org/10.1016/j.jbef.2020.100403

Todorof, M. (2018, August). Shariah-compliant fintech in the banking industry. In ERA Forum (Vol. 19, No. 1, pp. 1-17). Springer Berlin Heidelberg. Retrieved from https://link.springer.com/article/10.1007/s12027-018-0505-8

Yeon, J. I., Lee, J. D., \& Baek, C. (2020). A tale of two technological capabilities: Economic growth revisited from a technological capability transition perspective. The Journal of Technology Transfer, 1-32. Retrieved from https://link.springer.com/article/10.1007/s10961-020-09809-2

Yumna, A. (2019). Examining financial needs of banking customers for product development in Islamic banking in Indonesia. International Journal of Islamic and Middle Eastern Finance and Management, 12(5), 712-726. https://doi.org/10.1108/IMEFM-11-2018-0378 
